\title{
Review
}

\section{The Image before the Weapon: A Critical History of the Distinction between Civilian and Combatant}

\author{
Helen M. Kinsella \\ Cornell University Press, Ithaca, NY, 2011, 264pp., £24.95/\$39.95 \\ ISBN: 978-0801449031
}

Contemporary Political Theory (2013) 12, e14-e16. doi:10.1057/cpt.2013.31

The Obama administration's targeting of both high-level and low-level militants and 'combatants' - including the use of 'signature-strikes' targeting people in Pakistan, Yemen, Somalia and elsewhere based on activities other than openly fighting against US or allied forces - is only the latest controversy over the meaning of 'civilian' and the kinds of treatment persons so designated are owed. The use of visual surveillance technologies and artificial intelligence to identity 'signatures' of militants and to drop missiles on them, and then the post hoc labeling of all men killed as 'combatants' exemplify the two political problems at the heart of this book. The first is enforcing the civilian/combatant distinction. The second, perhaps even more important one, is deciding upon who counts as a 'civilian' in the first place. This is but one contemporary controversy that demonstrates the need for the kind of timely, erudite intervention that Kinsella provides in The Image before the Weapon - an authoritative critical history of the 'principle of distinction' that deeply informs our current political condition.

In this highly anticipated book, Kinsella deepens and expands her earlier work on the discourse of gender in early modern formulations of the civilian/combatant distinction with a tour de force whose influence transcends disciplinary divisions and speaks to some of the thorniest ethical issues in contemporary warfare. What is a civilian? What is a combatant? Who is to judge and on what grounds? In seeking the answers to these and other questions, Kinsella diverges from classic works in political theory that attempt to discern universal rules from various ethical perspectives or from existing laws and norms. Instead, she performs a Foucaultian genealogy of the principle of distinction that focuses on how the concept of 'civilian' came to be seen as self-evident in the first place. Epic in its ambition and scope yet tightly focused and accessibly argued, The Image Before the Weapon is a significant achievement in critical theorizing that speaks as much to contemporary debates about

(C) 2013 Macmillan Publishers Ltd. 1470-8914 Contemporary Political Theory Vol. 12, 4, e14-e16 www.palgrave-journals.com/cpt/ 
counterinsurgency strategy and the political dynamics of civil wars as it does to current interpretations of medieval philosophy.

At a time in which so much attention is given to debates over what compliance with the norm of distinction between civilian and combatant would entail and attention to the deliberative processes that produce decisions and justifications for the shape of norms in international society more generally, Kinsella argues that international law does not simply regulate the treatment of civilians and combatants; it is also productive of this very distinction. She argues that the concepts and categories of combatant and civilian cannot be taken as self-evident either within international humanitarian law or in conflicts' (p. 5). The categories of civilian and combatant must, therefore, be produced by the very norms that purport to regulate the protection of civilians, and by the consistent reiteration of such principles. The civilian/combatant distinction, which is taken to be the bedrock of international humanitarian law, in fact signals this body of law's 'most radical crisis' (p. 6).

Kinsella highlights the indeterminacy of the civilian/combatant distinction through a series of chapters that spans medieval and early modern political theory, the history of the laws of war and their development, and the practices embodying and inspiring understandings of what it means to be a 'civilian' from diverse conflicts, including the contemporary 'war on terror', the US Civil War and US Indian wars, the Algerian war for independence against the French, and the Salvadorean and Guatemalan civil wars of the 1980s. Deploying a genealogical mode of reading, which takes the instability and indeterminacy of concepts as a condition for politics rather than failures of politics (p. 191), Kinsella argues that the discourses of gender, civilization and innocence, which stabilize the meaning of 'civilian', are not tightly connected. They are, instead, a diffuse series, which 'may unravel and fray as often as it knots at particular historical moments' (p. 8). Kinsella analyzes defining moments in the development of the laws of war and the civilian/combatant distinction in a broadranging series of chapters, juxtaposing the work of classical theorists of the just war such as James Turner Johnson, Theodor Meron and Michael Walzer with the original works of Augustine, Aquinas and Gentile among others, finding contemporary works wanting in their efforts to find consistency in a tradition that is racked with incoherencies and ambivalences. In her re-reading of Grotius and Vitoria, Kinsella subtly traces tensions in concepts of immunity and protection from the violence of war that reveal civilian immunity as a privilege of Christian/civilized nations to grant in their sovereign mercy, and the discourse of women's 'natural' weakness and noninvolvement in war as a way to stabilize the distinction between those who should be spared and those who may be killed.

Each chapter discusses divergent moments in the formation of international law, but throughout Kinsella shows how past moments inform the present in the complex formations of gender, innocence and civilization that produce and reproduce the civilian/combatant distinction. For example, in her chapter on the US Civil War and the US Indian Wars, while discourses of gender protected white women working on 
behalf of the Confederate cause in which they might otherwise have been considered 'combatants', the discourse of civilization then discriminated against individuals who might otherwise have been considered civilians, allowing for atrocities against Native Americans. 'The killing of women and children - otherwise antithetical to the standards of civilization - is made intelligible when those same women and children are said to be outside of civilization, and in turn, pose a potential threat to it' (p. 20). The instability of the discourse of innocence in securing the definition of civilian is likewise shown in the adjudication of innocence as political passivity in the civil wars of Guatemala and El Salvador in the 1980s, making political neutrality impossible and allowing for entire villages or regions to be designated either supportive of the government or hostile, which enabled 'scorched earth' techniques and genocide.

Such examples illustrate the stakes of the indeterminate nature of the civilian/ combatant distinction, and how practices of making this distinction have productive effects not only for the question of who is entitled to protection and who may be killed, but also in terms of how international order is constituted. Kinsella forcefully argues that measuring success or failure of the norm of civilian immunity by whether or not actors adhere to this norm defines 'success' too narrowly: the distinction can serve to protect 'civilians' but it also serves to protect 'civilization' while performatively reiterating the substance of these categories. In so doing, Kinsella's work provides us with the grounds for nothing less than the reconsideration of the foundations of the international order, as she shows how the discourse of civilization - in particular, what civilization requires of whom in regard to whom lies at the heart of international law, as do discourses of sex and sex differences (both of which are conditioned by idea of innocence). Concluding with an Arendtian discussion of the importance of understanding as that which allows us to 'think what we are doing' (p. 197), Kinsella's book also makes the case that such genealogical work is crucial for creating the possibility to engage politically without presuming a fixed distinction between civilian and combatant, together with the possibility of asking about how such a distinction should be made anew. Her work will be read, assigned and cited for years to come across diverse subfields in political theory and International Relations (IR), such as feminist security studies, post-colonial theory, ethics and IR, international legal theory and early modern political thought.

Lauren Wilcox

Centre for Gender Studies, University of Cambridge, Cambridge CB2 3EN, UK 